\title{
A finding of Eptesicus gobiensis in an ancient salt mine in Iran and notes on the status of this bat in the Middle East (Mammalia: Chiroptera)
}

\author{
Petr Benda ${ }^{1,2}$ \& Marjan Mashkour ${ }^{3}$ \\ ${ }^{1}$ Department of Zoology, National Museum (Natural History), Václavské nám. 68, \\ 11579 Praha 1, Czech Republic \\ ${ }^{2}$ Department of Zoology, Faculty of Science, Charles University, Viničná 7, 12844 Praha 2, Czech Republic \\ ${ }^{3}$ Department of Archaeozoology and Archaeobotany, National Museum of Natural History, \\ 55 rue Buffon, 75005 Paris, France
}

Benda P. \& Mashkour M., 2021: A finding of Eptesicus gobiensis in an ancient salt mine in Iran and notes on the status of this bat in the Middle East (Mammalia: Chiroptera). - Journal of the National Museum (Prague), Natural History Series 190: 61-72.

\begin{abstract}
Two mummified bats were found in an ancient salt mine near Chehrabad, NW Iran. One complete and one partial skeletons, both associated with parts of the pelage, were identified as Eptesicus gobiensis, a bat species rare in the Middle East. The comparison of skull and statistical evaluation of craniodental data showed this bat to belong to the identical taxon as the mummified bats previously collected in Qutur Su caves, NW Iran; this part of Iran is thus an area of broader distribution of this bat, the second record reported here confirms its preference for dry upper plateaus. This Iranian population exhibits much similarity with E. gobiensis bobrinskoi living in lowland deserts of Kazakhstan, but it simultaneously shows morphological and ecological differences from the Kazakhstani populations. Therefore, the population of Iran is here tentatively identified as E. g. cf. bobrinskoi. The species rank of E. gobiensis was found to be composed of three morphotypes living in three separate ranges, E. g. gobiensis in mountain plateaus of Central Asia, E. g. bobrinskoi in lowlands of Kazakhstan, and E. g. cf. bobrinskoi in NW Iran. However, the phylogenetic and taxonomic statuses of the Iranian morphotype still remain to be elicudated.
\end{abstract}

Keywords: Bats, Eptesicus, Iran, archaeozoology, morphometry

Received: 28 June 2021 | Accepted: 19 August 2021 | Published on-line: 6 September 2021

\section{Introduction}

The Gobi serotine, Eptesicus gobiensis Bobrinskoj, 1926, is a small-sized and pale coloured bat, now considered as occurring across a broad belt of dry areas in Asia, stretching from the Caucasus region in the west to the Gobi Desert in the east. While numerous findings of $E$. gobiensis are available from the Central Asian part of its distribution range, only few sites of records were published from the southern and western parts of the range (Artyushin et al. 2012, Benda \& Gaisler 2015). 
The Gobi serotine was described based on a single male specimen collected at Burhastejtala (= NE of Cogtcècij, eastern Gobi Altai Mts., south-central Mongolia; ca. $43^{\circ} 50^{\prime} \mathrm{N}, 105^{\circ} 45^{\prime} \mathrm{E}$, $\sim 1450 \mathrm{~m}$ a. s. l.) by explorer and collector Nikolaj M. Prževalskij in August 1873 (Bobrinskoj 1926, cf. Prževalskij 1888). Originally, this bat was described and for a long time treated as the Central Asian subspecies (sometime as one of three Central Asian subspecies) of Eptesicus nilssonii (von Keyserling et Blasius, 1839), endemic to arid steppes of the mountainous plateaus of Mongolia and East Turkestan and mountain ranges of some adjacent countries (Bobrinskoj 1929, Kuzâkin 1944, 1950, 1965, Ellerman \& Morrison-Scott 1951, Bannikov 1954, Strelkov 1963, Stubbe \& Chotolchu 1968, Corbet 1978, Strelkov \& Šajmardanov 1983, Butovskij et al. 1985, Hanák \& Horáček 1986, etc.). Westernmost records of this taxon were reported from northern Kashmir, eastern Afghanistan, and western Tajikistan (Scully 1881, Felten 1971, Chakraborty 1983, Strelkov 1986, Benda \& Gaisler 2015).

However, based on differences found in the structures of the baculum and skull, Strelkov (1986) suggested to split E. nilssonii and E. gobiensis; these morphological variances were supported by a significant contrast in ecological requirements of both species $-E$. nilssonii s.str. is a boreal bat, distributed in the forest zone of Eurasia, while E. gobiensis is an eremial species, occuring only in dry open habitats. This species separation was then broadly accepted (see e.g. Hill \& Harrison 1987, Pavlinov \& Rossolimo 1987, Nader \& Kock 1990, Corbet \& Hill 1992, Horáček et al. 2000, Simmons, 2005).

On the other hand, Strelkov (1986) stressed a morphological similarity of the newly delimited E. gobiensis with another Asian congeneric bat, E. bobrinskoi Kuzâkin, 1935. The latter form is, similarly to E. gobiensis, a strict inhabitant of open arid habitats, namely the deserts and steppes of central and western Kazakhstan. Based on very convincing results of the molecular genetic and thorough morphological comparisons, Artyushin et al. (2012) suggested to consider E. bobrinskoi a junior synonym of E. gobiensis on the position of a subspecies. These two taxa differ to each other mainly in body size, E. g. gobiensis is a large form, with the forearm length (LAt) 37-44 mm and greatest length of skull (LCr) 15.1-16.1 mm, while E. g. bobrinskoi is a small bat, with LAt 34-37 mm and LCr 14.4-15.5 mm (for other dimensions see Table 1). These bats also differ in preferred altitude of the inhabited arid habitats, the former bat is known from mountainous areas, while the latter bat is an inhabitant of lowland regions only.

Additionally, bats morphologically very similar to E. g. bobrinskoi were documented from the upper areas of the Middle East and Caucasus. Kuzâkin $(1944,1950)$ mentioned a specimen originating in North Ossetia of the Russian Caucasus and Harrison (1963) reported on a finding of a series of bats from Guter-Su [= Qutur Su], north-western Iran. Although these specimens were identified as E. bobrinskoi, the bat of arid lowlands, the habitats of these records are quite unusual for this taxon, subalpine or alpine positions of high mountains $(>1,500 \mathrm{~m}$ a. s. l. at Fasnal, North Ossetia; >2,500 m a. s. l. at Qutur Su, NW Iran). Due to this unusual ecology and also due to the juvenile age of some of these specimens, Hanák \& Horáček (1986) considered these records as not fully grown individuals of $E$. nilssonii. Such an opinion was followed by the subsequent authors (see Koopman 1994, Benda \& Horáček 1998, Horáček et al. 2000, Simmons 2005).

However, Benda \& Reiter (2006) collected a new series of bats in north-western Iran, under identical conditions as reported by Harrison (1963); three semi-mummified carcasses were found in sulphuric caves on the northern slope of Mount Sabalan near the thermal spa resort of Qutur Su. These caves act as a natural trap for many insects and small vertebrates by killing them with sulphuric fumes - at least seven species of bats, and also insectivores, small rodents, birds, and numerous insects were found dead there (see Benda et al. 2012). The results of a morphological comparison made by Benda \& Reiter (2006) of the newly collected bats as well as the series of bats reported by Harrison (1963), showed a close similarity of the Qutur Su bats to the samples of E. g. bobrinskoi from Kazakhstani lowland steppes. Similarly, the bat reported from North Ossetia, considered E. nilssonii by Hanák \& Horáček (1986), was shown by Artyushin et al. (2012) to be morphologically close to E. g. bobrinskoi. 
These results clearly indicate that a very rare bat of the genus Eptesicus lives in the mountain positions of the regions at the western and south-western edges of the Caspian Sea. Only two occurrence sites have been available so far and no living individual was observed. In this contribution we bring description of a new record of this enigmatic bat, found in an ancient salt mine at Chehrabad, north-western Iran. The archeozoological studies of faunal remains collected in this mine brought 132 mammal remains, of them 103 belonged to anthropogenic deposits related to the consumption activities - sheep, goats, cattle, and pigs were the species consumed by the miners (Mashkour 2015). Other faunal remains belong to non anthropogenic deposits, among them six remains of bats were found, two of which were mummified and some represented by small skeletal parts (Mashkour 2015, Mashkour et al. 2020). Since the two mummified bat specimens are of special interest, they are described here.

\section{Material and Methods}

Two mummified individuals of small bats were found in an ancient salt mine at the village of Hamzehlu in 2011; one complete skeleton, one partial skeleton (with broken long bones and without skull), both associated with parts of the pelage (Fig. 1). The mine lies $4 \mathrm{~km} \mathrm{~N}$ of Chehrabad (correctly transliterated from the Farsi script as Chehrehabad) that gave its name to the ancient site, and $60 \mathrm{~km}$ WNW of Zanjan, Zanjan Province, Iran; 36 $54^{\prime} 51^{\prime \prime} \mathrm{N}, 47^{\circ} 51^{\prime} 25^{\prime \prime} \mathrm{E}$, ca. 1350 m a. s. l. (Fig. 2).
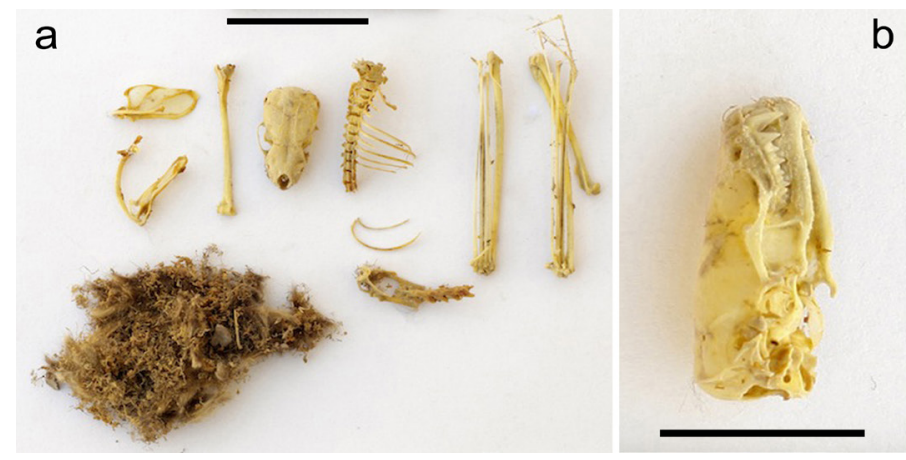

b

Fig. 1. Disassembled remains of a mummy of Eptesicus gobiensis discovered in the ancient salt mine of Chehrabad; $a$ - parts of the skeleton and pelage; $b$ - lateral view of skull and mandible; $c$ - ventral view of skull and mandible. Skale bars: $a=20 \mathrm{~mm}, b, c=10 \mathrm{~mm}$.

The site is located in the Mahneshan Range in the north-western part of the Iranian Plateau; geologically the area belongs to the Central Iran tectonic unit and is characterised by folded and thrusted Miocene marble and sandstone, with occurrences of gypsum and salt. These deformed sediments are discordantly overlain by a thin layer of terrestrial Quaternary, up to boulder sized sediments forming a prominent regional flat surface. The present landscape is mainly the result of late Pleistocene to Holocene dissection of the above mentioned successions and modern valley fill (Aali \& Stöllner 2015). The salt mining occurred in the mine during the fifth-fourth centuries BC (Achaemenid period), in the fifth century AD (Sassanian period), and also in the modern times (Aali et al. 2012, Aali \& Stöllner 2015). The miners extracted salt by pillar-and-chamber mining (timbering techniques seem not to have been used) and such underground spaces could be used as roost for various animals including bats. The age of the bat mummies is not apparent in any way, because of the suffusion of the bodies with the salt they could be remains of deep history as well as of a recent period. 


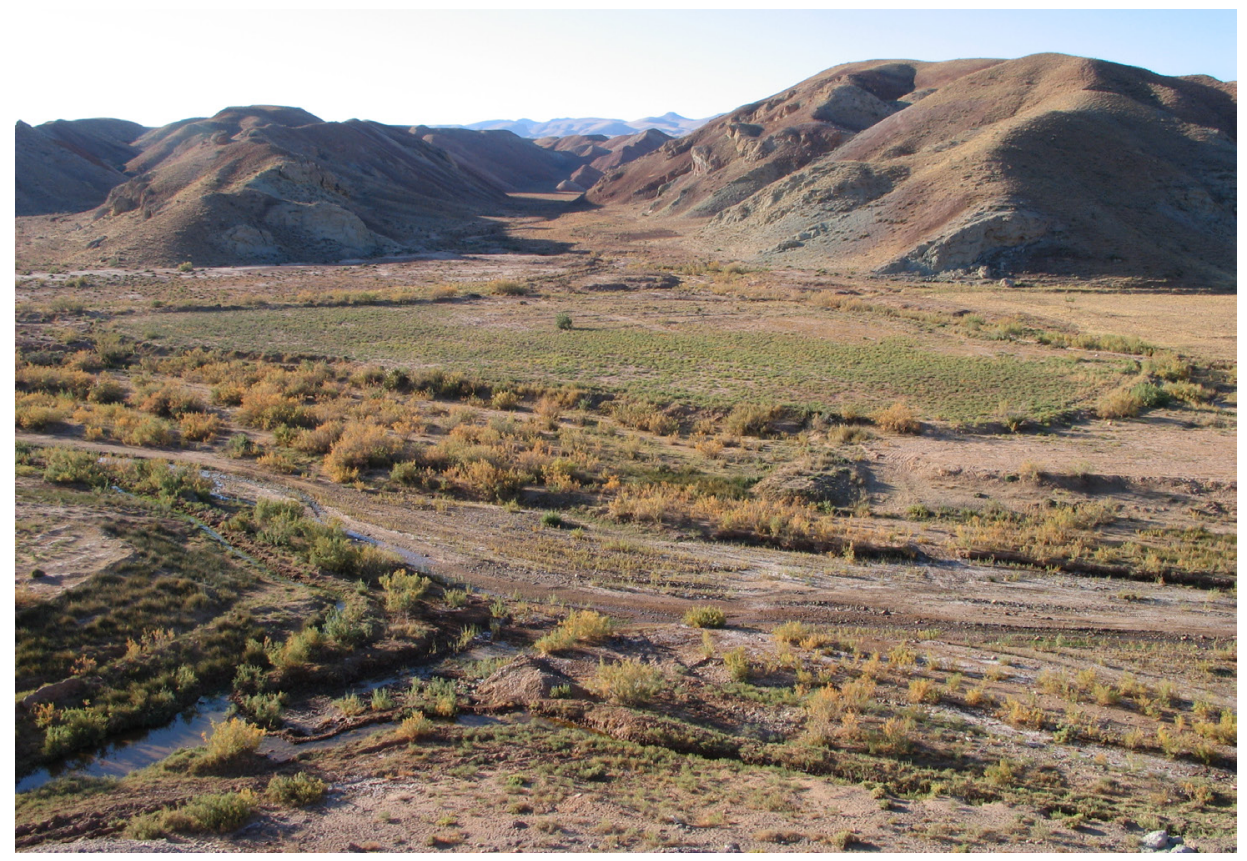

Fig. 2. The landscape of the ancient salt mine of Chehrabad, Zanjan Province, north-western Iran. A view out of the mine. Photo: M. Mashkour.

The two partly mummified specimens from Chehrabad are here compared with population samples of other small Eptesicus bats from Eurasia. This study follows the previous comparison by Benda \& Reiter (2006) and is exensively complemented of new comparative material of the relevant populations, including some type specimens. For comparative morphological and morphometrical purposes we used skulls, from external dimensions we took only the forearm length (LAt). The specimens were measured in a standard way using mechanical or optical callipers. Horizontal dental dimensions were taken on cingulum margins. The examined museum comparative material is given in Appendix. We evaluated 15 craniodental dimensions in each skull (13 measurements in the skull and maxillar tooth-row, three measurements in the mandible and mandibular tooth-row; for particular dimensions see Abbreviations) plus five indices that described the skull shape. Statistical analyses were performed using the Statistica 6.0 software.

\section{Abbreviations}

\section{Measurements}

LAt = forearm length; - LCr = greatest length of skull; - LCb = condylobasal length; - LaZ = zy gomatic width; - LaI = width of interorbital constriction; - LaInf = infraorbital witdth; - LaN = neurocranium width; $-\mathrm{LaM}=$ mastoidal width; $-\mathrm{ANc}=$ neurocranium height; $-\mathrm{ACr}=$ skull height (including tympanic bullae); - CC = rostral width between the labial margins of upper canines; $-\mathrm{M}^{3} \mathrm{M}^{3}=$ rostral width between the labial margins of third upper molars $\left(\mathrm{M}^{3}\right)$; $-\mathrm{CM}^{3}$ = length of upper tooth-row between the mesial margin of canine and distal margin of third molar $\left(\mathrm{M}^{3}\right) ;-\mathrm{LMd}=$ condylar length of mandible; $-\mathrm{ACo}=$ height of coronoid process; $-\mathrm{CM}_{3}$ = length of lower tooth-row between the mesial margin of canine and distal margin of third molar $\left(\mathrm{M}_{3}\right)$. 


\section{Collection acronyms}

BMNH = Natural History Museum, London, United Kingdom; - CUP = Department of Zoology, Charles University, Prague, Czech Republic; - NMP = National Museum (Natural History), Prague, Czech Republic; - SMF = Senckenberg Museum and Research Institute, Frankfurt am Main, Germany; - ZIN = Zoological Institute, Russian Academy of Sciences, St. Petersburg, Russia; - ZMMU = Zoological Museum, Moscow State University, Moscow, Russia.

\section{Others}

$\mathrm{A}=$ alcoholic preparation; $-\mathrm{B}=$ stuffed skin (balg); $-\mathrm{M}=$ mean; - max., min. $=$ dimension range margins; $-\mathrm{S}=$ skull; $-\mathrm{SD}=$ standard deviation; $-q=$ female; $-\hat{\sigma}=$ male.

\section{Results and Discussion}

Of the remains of two Chehrabad bat individuals, only the bat skeleton with skull associated could be compared morphologically, on the other hand, the bat skeleton without skull but with present more hairs underwent a genetic analysis. However, the isolation of any genetic material from the hairs failed, and thus just one bat was examined properly (hereafter the Chehrabad bat), only with help of the morphometric comparisons. The bone and hair remains from both bats show similar characteristic macroscopically and presumably both bats belong to an identical species.

The Chehrabad bat represents a representative of the genus Eptesicus Rafinesque, 1820, posessing its typical characters (single premolar in upper jaw, myotodont molars, broad and flattened neucranium, straight skull profile; Fig. 1), we compared it with representatives of small forms of the genus Eptesicus occurring in the Palaearctic southern Asia. All these bats belong to the E. nilssonii morpho-group; it comprises three morphotypes, E. nilsonii, E. gobiensis gobiensis, and E. g. bobrinskoi, the latter in two separate populations, of the lowland Kazakhstan and of the mountains of Iran (i.e., sensu Benda \& Reiter 2006). The comparison of skull dimensions (Table 1, Fig. 3) showed the Chehrabad bat to be in most respects belonging into the group of small-sized bats of the morpho-group, comprising mixture of the sam-

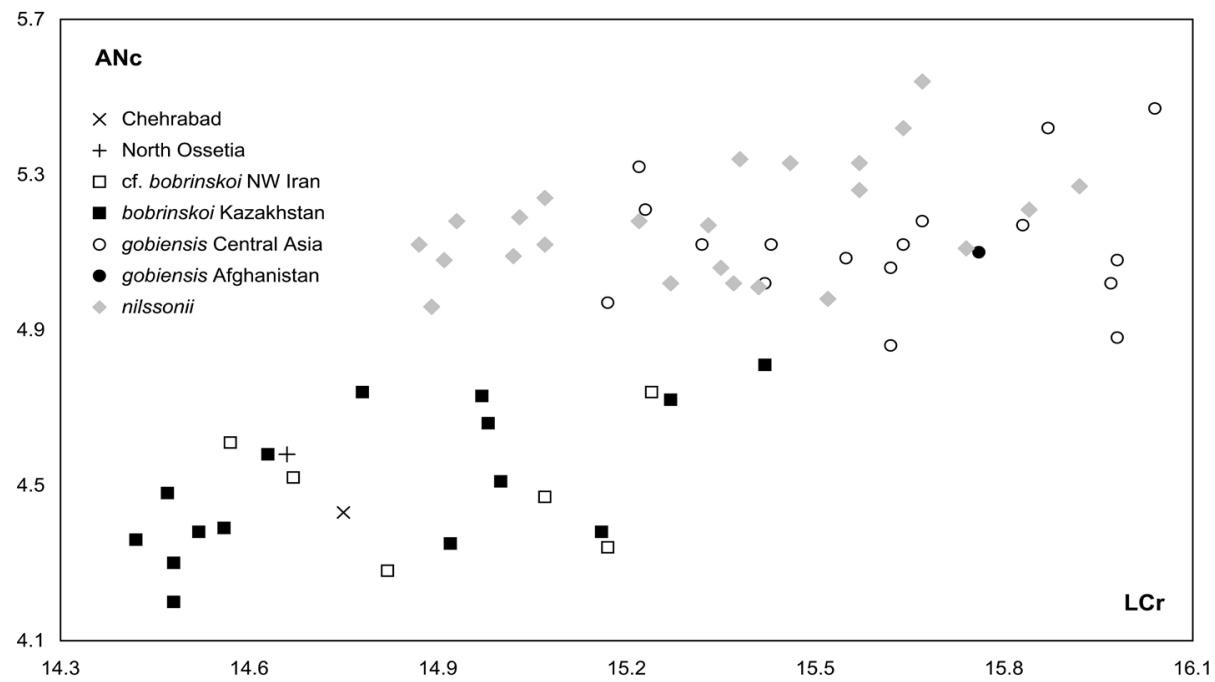

Fig. 3. Scatter plot of the greatest length of skull (LCr) against the height of neurocranium (ANc) in the Chehrabad bat and the comparative samples of the Eptesicus nilssonii morpho-group. Data in millimetres. 


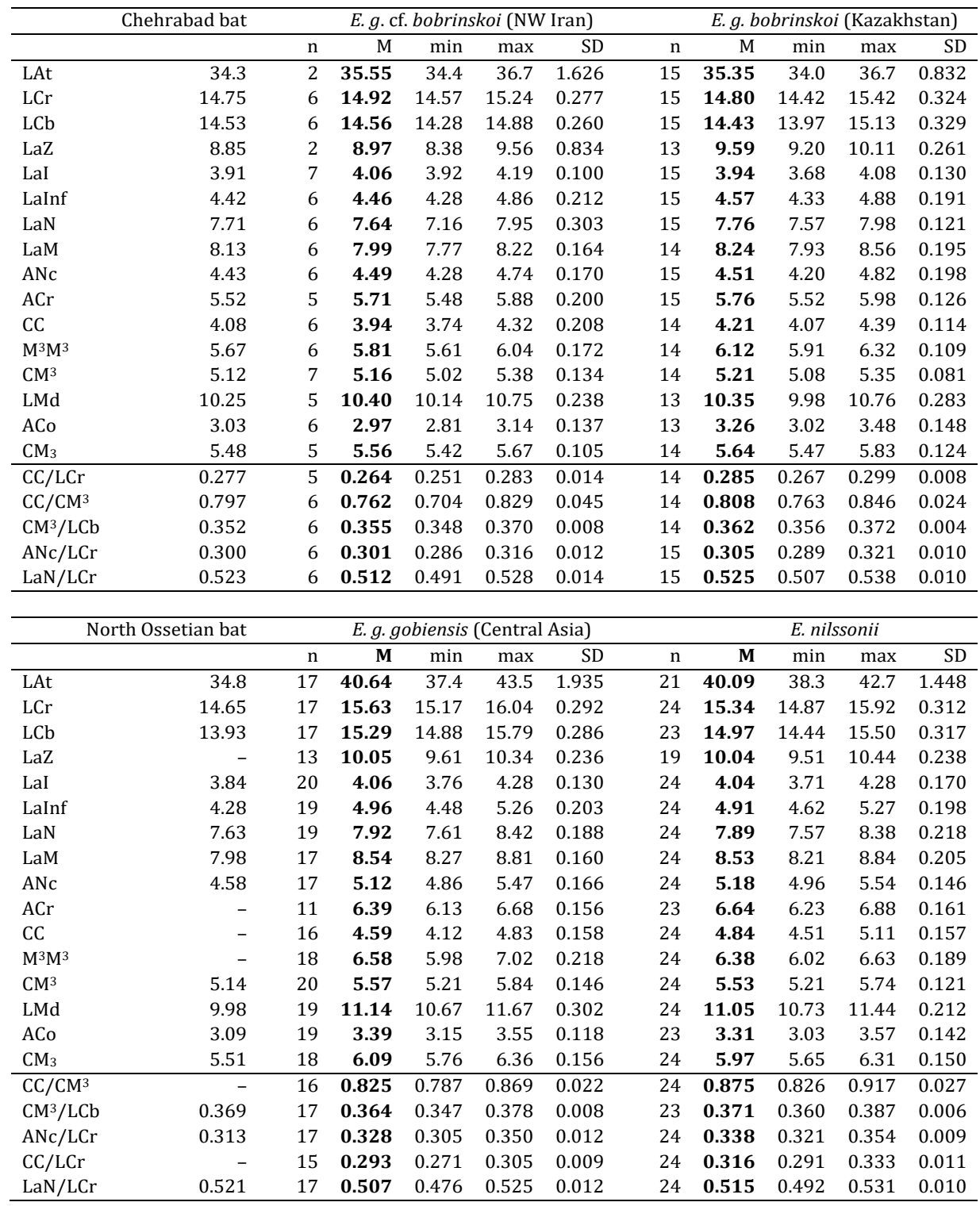

Table 1. Biometric data on the Chehrabad bat and comparative samples of Eptesicus nilssonii morphogroup. For dimension explanations see Abbreviations.

ples of E. g. bobrinskoi from Kazakhstan and from Iran, significantly smaller than the samples of the group of large bats, comprising E. gobiensis gobiensis from various parts of Central Asia and E. nilssonii occurring in the boreal zone of Eurasia. The most distinct characters which rate the Chehrabad bat among the bats of the bobrinskoi morphotype are the small size of skull (LCr $14.75 \mathrm{~mm}$ and $\mathrm{CM}^{3} 5.12 \mathrm{~mm}$, vs. $14.4-15.5 \mathrm{~mm}$ and 5.0-5.4 $\mathrm{mm}$ in the bobrinskoi morphotype, and $14.8-16.1 \mathrm{~mm}$ and $5.2-5.9 \mathrm{~mm}$ in the gobiensis s.str. and nilssonii morpho- 


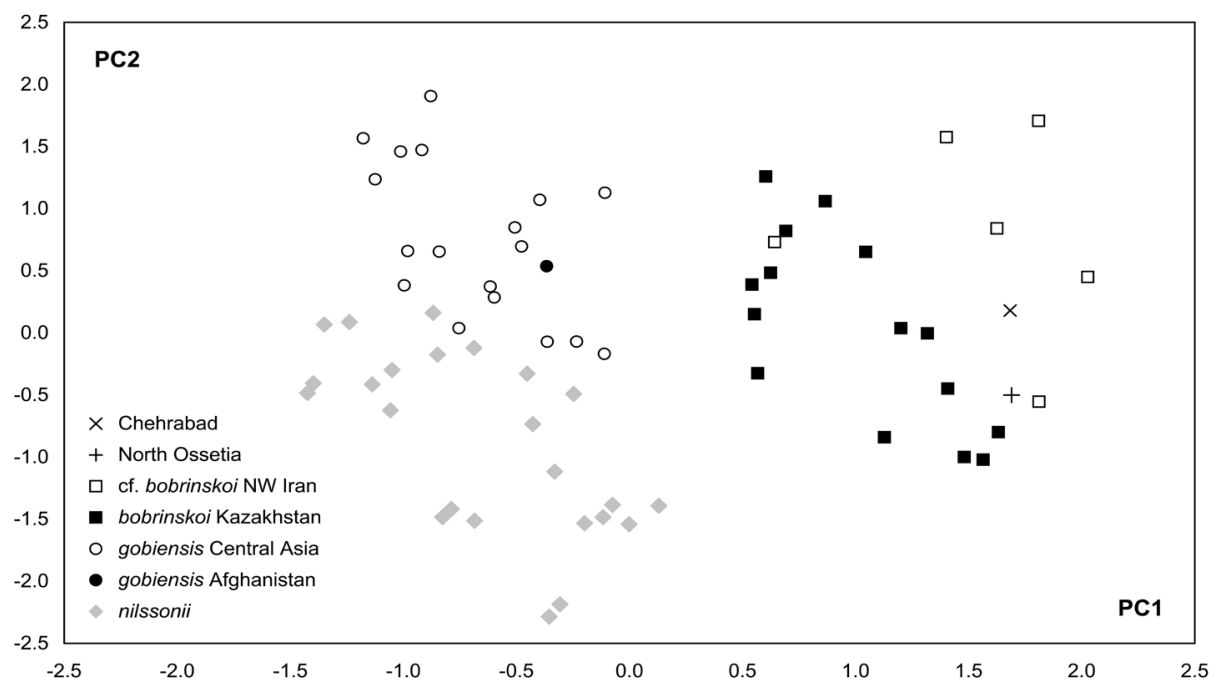

Fig. 4. Scatter plot of results of the principal component analysis of absolute and relative skull dimensions of the Chehrabad bat and the comparative samples of the Eptesicus nilssonii morpho-group.

types, respectively), combined with very low braincase (ANc $4.43 \mathrm{~mm}$, vs. $4.2-4.9 \mathrm{~mm}$ in bobrinskoi and 4.8-5.6 mm in gobiensis s.str. and nilssonii, respectively), see Fig. 3. The value of the relative height of braincase $(\mathrm{ANc} / \mathrm{LCr})$ is rather low in the Chehrabad bat $(0.300)$, i.e. as low as in the bobrinskoi morphotype (0.286-0.321), while below the range in the gobiensis s.str. and nilssonii morphotypes (0.305-0.354).

The principal component analysis of the skull absolute and relative dimensions as presented in Table 1 separated three groups of samples (Fig. 4; PC1 61.91\% of variance, PC2 $12.49 \%)$, the nilssonii morphotype, gobiensis s.str. morphotype, and bobrinskoi morphotype. The Chehrabad bat was placed in the cluster of samples of the latter morphotype. Within the cluster of the bobrinskoi samples, two partially overlapping subgroups are present, group of the bats from Kazakhstan and of bats from Iran (including the Chehrabad specimen). This separation within the bobrinskoi morphotype seems to be linked to slight differeces between these two populations in the skull shape; the skulls of the Iranian bats are on average slightly larger than the Kazakhstani samples (E. g. bobrinskoi s.str.), on the other hand, the Iranian bats have slightly narrower skulls, as present from the absolute values of most of the skull width dimensions (LaZ, LaInf, LaN, LaM, CC, $\mathrm{M}^{3} \mathrm{M}^{3}$, $\mathrm{LaN} / \mathrm{LCr}, \mathrm{CC} / \mathrm{LCr}$ ), and absolutely and relatively shorter rostra $\left(\mathrm{CM}^{3}, \mathrm{CM}_{3}, \mathrm{CM}^{3} / \mathrm{LCb}\right)$ than the bats from Kazakhstan (see Table 1).

The comparison of plain measurements as well as the statistical evaluation of the craniodental data showed coincident results. The species identity of the Chehrabad specimen, which due to presence of skull in the bat remains allowed the identification, seem to be clear, this bat belongs to the identical taxon as the bats collected in Qutur Su during two visits of the site in 1961 and 2006 (Harrison 1963, Benda \& Reiter 2006). On the other hand, these Iranian bats known now from two sites, although belonging to the bobrinskoi morphotype as defined above, exhibit certain fine morphological and obvious ecological differences from the populations of E. g. bobrinskoi s.str. from Kazakhstan (see also the comparison by Benda \& Gaisler 2015). Therefore, the population of Iran is here tentatively identified as E. g. cf. bobrinskoi, since its separate taxonomic status cannot be excluded. The real position of the Iranian population within the species rank of E. gobiensis could perhaps be elicudated only 
with help of a genetic comparison, which is possible only when a living bat or a fresh cadaver is available (the isolation of a genetic material failed also from the Qutur Su bats collected in 2006, when the analysis of the Palaearctic Eptesicus bats was prepared by Juste et al. 2013).

The new Iranian individual (or individuals) of E. g. cf. bobrinskoi was found in a relative proximity to Qutur $\mathrm{Su}$, the only site where this bat was found in Iran before, lying $158 \mathrm{~km}$ directly to north $\left(38^{\circ} 20^{\prime} 06^{\prime \prime} \mathrm{N}, 4^{\circ} 51^{\prime} 24^{\prime \prime} \mathrm{E}\right)$ of the Chehrabad mine. Thus, the north-western part of Iran is an area of broader distribution of this bat, and its second record confirms the preference for dry upper plateaus. On the other hand, this population seems to remain isolated in this habitat type of the region.

Another bat from the E. nilssonii morpho-group recorded from Iran was originally identified as E. nilssonii (Lay 1967), later as E. nilssonii gobiensis (DeBlase 1980), and finally as E. nilssonii nilssonii (Benda et al. 2012, Yusefi et al. 2019). This bat was collected at Sama (Mazandaran Province) in the forested northern slope of the Alborz Mts. at the altitude of ca. $1110 \mathrm{~m}$ a. s. l. Based on the biometric data provided by DeBlase (1980) showing a large-sized individual ( $\mathrm{LCr} 15.9 \mathrm{~mm}, \mathrm{CM}^{3} 5.3 \mathrm{~mm}$ ), Benda et al. (2012) excluded a possibility that this bat could represent a member of the bobrinskoi morphotype and suggested it belongs to the large-sized forms of the morpho-group (see also Table 1). Of the two species in this category, Benda et al. (2012) concluded that the respective bat pertains rather to E. nissonii than to E. g. gobiensis, with respect to the biogeographical and ecological conditions. The bat was recorded in the zone of dense forests in the Hyrcanian region of Iran, which directly continues to the Caucasian forest zone in the west, where E. nilssonii occurs, while the closest sites of the known occurrence of E. g. gobiensis in Tajikistan and Afghanistan, the Mazandaran locality is distant for more than $1500 \mathrm{~km}$ as a bee flies. Nevertheless, DeBlase (1980) did not provide dimensions of the braincase of the Mazandran specimen, and thus, the conclusion given by Benda et al. (2012) remains only tentative (although well supported), since only a detailed examination of the skull and braincase shape (besides the genetic data) could help with proper identification of this specimen (currently deposited at the Field Museum, Chicago; DeBlase 1980).

The above described morphometric comparison also enabled us to make an idea about species affiliation of the bat collected from near Fasnal in North Ossetia, Russian Caucasus (ca. $42^{\circ} 56^{\prime} \mathrm{N}, 43^{\circ} 49^{\prime} \mathrm{E}$ ) and identified by Kuzâkin $(1944,1950)$ as E. bobrinskoi (see above). The results of our comparison conform with the conclusions by Artyushin et al. (2012), who suggested this specimen to be a member of the bobrinskoi morphotype (see Figs. 3, 4 and Table 1). However, unlike all other populations assigned to E. gobiensis in its current sense (including gobiensis s.str., bobrinskoi and cf. bobrinskoi), the Ossetian bat originates from the densely forested northern slope of the Greater Caucasus range, i.e. from environmental conditions completely dissimilar from the ecological and biogeographical points of view to the lowland or montane arid steppes where other populations of the species occur. Moreover, and unlike the Chehrabad bat, the Ossetian specimen is an immature bat with no fully ossified wing joints (see also Artyushin et al. 2012) and its morphological comparison could give only tentative results - this bat certainly belongs to the nilssonii morpho-group, but its identity could be proved more likely with a help of molecular genetic analysis than the dimensional comparison. In summary, the Ossetian bat remains a mystery again and thus, the view presented by Hanák \& Horáček (1986) could be still valid.

In conclusion, the present morphometric comparison of sufficient amount of specimens from whole distribution range of E. gobiensis demonstrated existence of three morphotypes living in three separate ranges with its species rank. The large morphotype, E. g. gobiensis, occurs in dry mountain plateaus of Central Asia in the east of the species range. Two small morphotypes live in the western part of the range, E. g. bobrinskoi s.str. in lowland deserts of central and western Kazakhstan and E. g. cf. bobrinskoi in dry mountain plateaus of north-western Iran. However, their mutual phylogenetic relationships and the taxonomic status of the Iranian populations still remain to be determined. 


\section{Acknowledgements}

We thank Paula Jenkins, Daphne Hills, and Louise Tomsett (BMNH), Ivan Horáček (CUP), †Dieter Kock, †Gerhard Storch, and Irina Ruf (SMF), †Petr P. Strelkov and Galina I. Baranova (ZIN), and Sergei V. Kruskop (ZMMU), for accessing the museum specimens under their care. We would like to thank also Abolfazl Aali and Thomas Stöllner, the Iranian and German directors of the Chehrabad Douzlakh excavations, who gave us access to the bat specimens. We are grateful to the Iranian Cultural Heritage Organisation (Tehran, Iran), the German Mining Museum (Bochum, Germany), and the Archaeozoology/Archaeobotany reasearch team (AASPE) of the National Museum of Natural History (Paris, France) for their support. The study was also supported by the Ministry of Culture of the Czech Republic (\# DKRVO 2019-2023/6.IX.c, 00023252).

\section{References}

Aali A., Abar A., Boenke N., Pollard M., Rühli F. \& Stöllner T., 2012: Ancient salt mining and salt men: the interdisciplinary Chehrabad Douzlakh project in north-western Iran. - Antiquity Project Gallery 86 (333). URL: http://antiquity.ac.uk/projgall/aali333/ [accessed on 30 March 2021]

Aali A. \& Stöllner T., 2015: The archaeology of the salt miners: interdisciplinary research 2010-2014. - Bochum: Deutsches Bergbau-Museum, 145 pp.

Artyushin I. V., Lebedev V. S., Smirnov D. G. \& Kruskop S. V., 2012: Taxonomic position of the Bobrinski's serotine (Eptesicus bobrinskoi, Vespertilionidae, Chiroptera). - Acta Chiropterologica 14: 291-303. https://doi.org/10.3161/150811012x661620

Bannikov A. G., 1954: Mlekopitaûŝie Mongol'skoj Narodnoj Respubliki [Mammals of the Mongolian People's Republic]. - Trudy Mongol'skoj Komissii 53: 1-669 (in Russian).

Benda P. \& Gaisler J., 2015: Bats (Mammalia: Chiroptera) of the Eastern Mediterranean and Middle East. Part 12. Bat fauna of Afghanistan: revision of distribution and taxonomy. Acta Societatis Zoologicae Bohemicae 79: 267-458.

Benda P. \& Horáček I., 1998: Bats (Mammalia: Chiroptera) of the Eastern Mediterranean. Part 1. Review of distribution and taxonomy of bats in Turkey. - Acta Societatis Zoologicae Bohemicae 62: 255-313.

Benda P. \& Reiter A., 2006: On the occurrence of Eptesicus bobrinskoi in the Middle East (Chiroptera: Vespertilionidae). - Lynx, n. s. 37: 23-44.

Benda P., Faizolâhi K., Andreas M., Obuch J., Reiter A., Ševčík M., Uhrin M., Vallo P. \& Ashrafi S., 2012: Bats (Mammalia: Chiroptera) of the Eastern Mediterranean and Middle East. Part 10. Bat fauna of Iran. - Acta Societatis Zoologicae Bohemicae 76: 163-582.

Bobrinskoj N. A., 1926: Predvaritel'noe soobŝenie o letučih myšah (Chiroptera) iz Central'noj Azii [Preliminary report on bats (Chiroptera) from Central Asia]. - Doklady Akademii Nauk SSSR 1926: 95-98 (in Russian, with a subtitle in French).

Bobrinskoj N., 1929: Bats of Central Asia. - Ežegodnik Zoologičeskogo Muzeâ Akademii Nauk SSSR 1929: 217-244.

Butovskij P. M., Šajmardanov R. T. \& Strelkov P. P., 1985: Otrâd Rukokrylye - Chiroptera Blumenbach, 1779 [Order Bats - Chiroptera Blumenbach, 1779]. - In: Bekenov A., Butovskij P. M., Kasabekov B. B., Lankin P. M., Strelkov P. P., Stogov I. I., Fedosenko A. K., Šajmardanov R. T. \& Šubin I. G. (eds.): Mlekopitaûŝie Kazahstana v četyreh tomah. Tom četvertyj. Nasekomojadnye i rukokrylye [Mammals of Kazakhstan in four volumes. Fourth volume. Insectivores and bats]. Pp. 125-260. - Alma-Ata: Nauka Kazahskoj SSR, 280 pp (in Russian, with a subtitle in English).

Chakraborty S., 1983: Contribution to the knowledge of the mammalian fauna of Jammu and Kashmir, India. - Records of the Zoological Survey of India, Miscellaneous Publication, Occasional Paper 38: 1-129. 
Corbet G. B., 1978: The mammals of the Palaearctic region: a taxonomic review. - London \& Ithaca: British Museum (Natural History) \& Cornell University Press, $314 \mathrm{pp.}$

Corbet G. B. \& Hill J. E., 1992: The mammals of the Indomalayan region: a systematic review. - New York: Oxford University Press, 488 pp.

DeBlase A. F., 1980: The bats of Iran: systematics, distribution, ecology. - Fieldiana: Zoology, N. S. 4: i-xvii+1-424. https://doi.org/10.5962/bhl.title.3206

Ellerman J. R. \& Morrison-Scott T. C. S., 1951: Checklist of Palaearctic and Indian mammals 1758 to 1946. - London: British Museum (Natural History), 810 pp.

Felten H., 1971: Eine neue Art der Fledermaus-Gattung Eptesicus aus Kleinasien (Chiroptera: Vespertilionidae). - Senckenbergiana Biologica 52: 371-376.

Hanák V. \& Horáček I., 1986: Zur Südgrenze des Areals von Eptesicus nilssoni (Chiroptera: Vespertilionidae). - Annalen des Naturhistorischen Museums in Wien 88-89 B: 297-308.

Harrison D. L., 1963: Report on a collection of bats (Microchiroptera) from N. W. Iran. Zeitschrift für Säugetierkunde 28: 301-308.

HillJ.E.\& Harrison D. L., 1987:ThebaculumintheVespertilionidae (Chiroptera:Vespertilionidae) with a systematic review, a synopsis of Pipistrellus and Eptesicus, and the descriptions of a new genus and subgenus. - Bulletin of the British Museum (Natural History), Zoology 52: 225-305. https://doi.org/10.5962/p.18307

Horáček I., Hanák V. \& Gaisler J., 2000: Bats of the Palearctic region: a taxonomic and biogeographic review. - In: Wołoszyn B. W. (ed.): Proceedings of the VIIIth European Bat Research Symposium. Vol. I. Approaches to biogeography and ecology of bats. Pp. 11-157. - Kraków: Chiropterological Information Center, Institute of Systematics and Evolution of Animals PAS, 280 pp.

Juste J., Benda P., Garcia-Mudarra J. L. \& Ibáñez C., 2013: Phylogeny and systematics of Old World serotine bats (genus Eptesicus, Vespertilionidae, Chiroptera): an integrative approach. Zoologica Scripta 42: 441-457. https://doi.org/10.1111/zsc.12020

von Keyserling A. Graf \& Blasius I. H., 1839: Uebersicht der Gatungs- und Artcharaktere der europäischen Fledermäuse. - Archiv für Naturgeschichte 5: 293-331.

Koopman K. F., 1994: Chiroptera: Systematics. - In: Niethammer J., Schliemann H. \& Starck D. (eds.): Handbuch der Zoologie. Band VIII. Mammalia. Teilband 60. Pp. 1-217. - Berlin \& New York: Walter de Gruyter, vii+224 pp.

Kuzâkin A. P., 1935: Novye dannye po sistematike i geografičeskomu rasprostraneniû letučih myšej (Chiroptera) v SSSR [New data on systematics and geographical distribution of bats (Chiroptera) in the Soviet Union]. - Bûlleten Moskovskogo Obŝestva Ispytatelej Prirody, Otdel' Biologičeskij 44: 428-438 (in Russian, with a summary in German).

Kuzâkin A. P., 1944: II. Otrâd rukokrylye. Ordo Chiroptera [II. Order Bats. Ordo Chiroptera]. - In: Bobrinskij N. A., Kuznecov B. A. \& Kuzâkin A. P. (eds.): Opredelitel' mlekopitaûŝih SSSR [Identification key to the mammals of the Soviet Union]. Pp. 59-108. - Moskva: Gosudarstvennoe Izdatel'stvo «Sovetskaâ Nauka», 440 pp (in Russian).

Kuzâkin A. P., 1950: Letučie myši (Sistematika, obraz žizni i pol'za dlâ sel'skogo i lesnogo hozâjstva) [Bats (systematics, life history, and utility in agriculture and forestry)]. - Moskva: Sovetskaâ Nauka, 444 pp (in Russian).

Kuzâkin A. P., 1965: Otrâd Rukokrylye. Ordo Chiroptera [Order Bats. Ordo Chiroptera].-In: Bobrinskij N. A., Kuznecov B. A. \& Kuzâkin A. P. (eds.): Opredelitel' mlekopitaûsih SSSR [Identification key to the mammals of the Soviet Union]. Pp. 79-116. - Moskva: Prosveŝenie, 384 pp (in Russian).

Lay D. M., 1967: A study of the mammals of Iran, resulting from the Street Expedition of 196263. - Fieldiana: Zoology 54: 1-282. https://doi.org/10.5962/bhl.title.2961

Mashkour M., 2015: Faunal report of the 2010 and 2011 excavation campaings. - In: Aali A. \& Stöllner T. (eds.): The archaeology of the salt miners: interdisciplinary research 20102014. Pp. 112-117. - Bochum: Deutsches Bergbau-Museum, 145 pp.

Mashkour M., Fathi H. \& Davoudi H., 2020: Human and animals interactions in the Douzlakh Chehrabad. - In: Stöllner T., Aali A. \& Bagherpour-Kashan N. (eds.): Tod im Salz: Eine 
achäologische Ermittlung in Persien. Pp. 219-224. - Bochum: Deutsches Bergbau-Museum, $368 \mathrm{pp}$.

Nader I. A. \& Kock D., 1990: Eptesicus (Eptesicus) bottae (Peters 1869) in Saudi Arabia with notes on its subspecies and distribution (Mammalia: Chiroptera: Vespertilionidae). Senckenbergiana Biologica 70: 1-13.

Pavlinov I. Â. \& Rossolimo O. L., 1987: Sistematika mlekopitaûsiih SSSR [Systematics of the mammals of the Soviet Union]. - Sbornik Trudov Zoologičeskogo Muzeâ MGU 25: 1-285 (in Russian).

Prževalskij N. M., 1888: Ot Kâhty na istoki Želtoj reki, izsledovanie severnoj okrainy Tibeta i put' čerez Lob-Nor po bassejnu Tarima [From Kyakhta to the springs of the Yellow River, explorations of the northern margins of Tibet and the journey over the Lobnor through the Tarim Basin]. - S.-Peterburg: Tipografiâ V. S. Balaševa, 536 pp (in Russian).

Scully J., 1881: On the mammals of Gilgit. - Proceedings of the Zoological Society of London 1881: 197-209. https://doi.org/10.1111/j.1096-3642.1881.tb01278.x

Simmons N. B., 2005: Order Chiroptera. - In: Wilson D. E. \& Reeder D. M. (eds.): Mammal species of the world. A taxonomic and geographic reference. Third edition. Volume 1. Pp. 312-529. - Baltimore: The John Hopkins University Press, xxxviii+743 pp.

Strelkov P. P., 1963: II. Otrâd Chiroptera - Rukokrylye [II. Order Chiroptera - Bats]. - In: Sokolov I. I. (ed.): Mlekopitaûŝie fauny SSSR. Čast' 1 [Mammals of the fauna of the Soviet Union. Part 1]. Pp. 122-218. - Moskva \& Leningrad: Izdatel'stvo Akademii nauk SSSR, 640 pp (in Russian).

Strelkov P. P., 1986: Gobijskij kožanok (Eptesicus gobiensis Bobrinskoy, 1926) - novyj vid rukokrylyh fauny Palearktiki [The Gobi serotine (Eptesicus gobiensis Bobrinskoy, 1926) - a new bat species of the Palaearctic fauna]. - Zoologičeskij Žurnal 65: 1103-1108 (in Russian, with a summary in English).

Strelkov P. P. \& Šajmardanov R. T., 1983: Novye dannye o rosprostranenii letučih myšej (Chiroptera) v Kazahstane [New data on the distribution of bats (Chiroptera) in Kazakhstan]. - Trudy Zoologičeskogo Instituta Akademii Nauk SSSR 119: 3-37 (in Russian).

Stubbe M. \& Chotolchu N., 1968: Zur Säugetierfauna der Mongolei. Ergebnisse der MongolischDeutschen Biologischen Expeditionen seit 1962, Nr. 30. - Mitteilugen aus dem Zoologischen Museum in Berlin 44: 1-121.

Yusefi G. H., Faizolahi K., Darvish J., Safi K. \& Brito J. C., 2019: The species diversity, distribution, and conservation status of the terrestrial mammals of Iran. - Journal of Mammalogy 100: 55-71. https://doi.org/10.1093/jmammal/gyz002

\section{APPENDIX}

\section{List of the material examined}

\section{Eptesicus gobiensis cf. bobrinskoi Kuzâkin, 1935}

Iran (7): $1 \hat{\jmath}, 2$ o $ᄋ, 4$ inds. (BMNH 63.1184., 63.1186., 63.1189., 63.1190. [S], NMP 9089090892 [S+A]), Qutur Su, Mt. Sabalan, 21 August 1961, leg. Aberystwyth University Expedition, 5 June 2006, P. Benda \& A. Reiter.

Russia (1): 1 ð (ZMMU S-7799 [S+B]), North Ossetia, near Fasnal, 7 August 1926, leg. B. Kornaev.

\section{Eptesicus gobiensis bobrinskoi Kuzâkin, 1935}

Kazakhstan (18): 1 (ZIN 61694 [S+B]), Aryskumy desert, 27 km SSE of Mustafa, 25 July 1974, leg. I. Stogov; - 1 q (ZIN 62247 [S+B]), 10 km NW of Čelkar, 18 June 1975, leg. P. Strelkov; - 1 ふૈ, 1 o (ZIN 65104, 65121 [S+B]), Sarysu river, between Džilandy and Kense, 
120 km SSE of Džezkazgan, 13 June 1977, leg. P. Strelkov; - 1 đ̊ (ZIN 68618 [S+B]), Karakum Meteorologic Station, Bokdok Valley, 180 km N of Džusaly, 21 June 1980, leg. P. Strelkov; 3 우 (ZMMU, S-5081, S-5082 [S+A], S-5091 [A], type series of Eptesicus bobrinskoi Kuzâkin, 1935), Tûlek well, 65 km E of Aralskoe More, 20 June 1928, leg. S. P. Naumov; -4 inds. (ZMMU S-60608, S-60609 [S+B], S-60610, S-60611 [B]), 30 km N of Yrgyz, tomb, 9 June 1956, leg. Û. Dubrovskij; - 6 우우 (ZIN 62240-62242, 62244-62246 [S+B]), Žetybaj well, 150 km N of KzylOrda, 5 \& 8 June 1975, leg. P. Strelkov.

\section{Eptesicus gobiensis gobiensis Bobrinskoj, 1926}

Aghanistan (1): 1 q (SMF 38879 [S+A]), Kabul, 1800 m, 3 May 1965, leg. D. Meyer-Oehme. China (1): $1 \curvearrowright$ (ZMMU S-195543 [mummy]), Cinhaj, Dulan, fields near Balong; $36.024^{\circ} \mathrm{N}$, $97.520^{\circ}$ E, date unlisted, leg. A. A. Lisovskij \& E. V. Obolenskaâ.

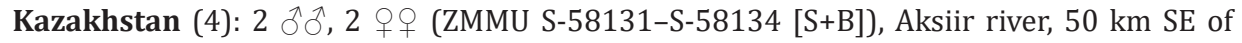
Zajsan, 14 July 1955, leg. V. Lebedev.

Kirghizstan (6): 6 우 (CUP CT84/24-29 [S+A]), Ala-Arča reserve, 30 July 1984, leg. J. Červený \& I. Horáček.

Mongolia (9): 1 (ZMMU S-116980 [S+B]), 6 km E of Baân-Unger, Mongolian Altai Mts., 4 August 1978, leg. D. I. Bibikov; - 1 ते (ZMMU S-42037 [S+B]), middle zone of Bitgotin'am, Gobi Altai Mts, 2.300 m a. s. l., 30 June 1945, leg. A. G. Bannikov; - 1 ઈ, 1 ind. (ZMMU S-42035, S-42036 [S+B]), Čun Hudum, Bajan-Uagan, Southern Mongolian Altai Mts., 7 July 1945, leg. A. G. Bannikov; -2 우 (ZMMU S-40127, S-40128 [S]), Kov. Ingen, Sebestej, Džungarian Gobi desert, 30 July 1943, leg. A. G. Bannikov; - 2 우 (ZMMU S-167530, S-167531 [S]), TumynCogt, 60 km E of Idermeg, summer 1980, leg. Û. Gorelov; - 1 ind. (ZMMU S-145701 [S]), Mongolia (undef.), 1976, leg. V. M. Neronov.

\section{Eptesicus nilssonii (von Keyserling et Blasius, 1839)}

Czech Republic (19): 1 đ̊ (NMP 91133 [S]), Dlouhá Ves, Franz-Franz mine, 30 January 1959, leg. V. Hanák; - 1 + (NMP 91144 [S+B]), Malé Karlovice, Tísňavy, 5 June 1973, leg. V. Bejček; 4 đđં, 3 우우 (NMP 91136, 91138, 91139 [S+B], 91123, 91124, 91126, 91127 [S]), Mariánská Hora, Bílá Desná mine, 24 February 1958, 13 February 1962, 2 December 1964, leg. V. Hanák; - 1 đ (NMP 91128 [S]), Mikulov u Teplic, 13 March 1958, leg. V. Hanák; - 1 đ̊ (NMP 91146 [S+B]), Orlické Záhoří, 10 February 1977, leg. P. Rybáŕ; - 1 9 (NMP 91152 [S]), Pohorská Ves, Žofín forest, 16 June 1973, leg. V. Vohralík; - 1 O (NMP 91140 [S]), Rokytnice v Orlických horách, Hanička fortress, 22 January 1965, leg. J. Sklenáŕ; - 1 ô (NMP 91132 [S+B]), Suchá Rudná, 30 January 1959, leg. V. Hanák; - 1 ind. (NMP 91151 [S]), Šumava Mts., leg. J. Červený; - 2 우 (NMP 91121, 91122 [S+B]), Vrbno near Blatná, 4 and 5 June 1956, leg. V. Hanák; 2 ô đે (NMP 91130, 91131 [S]), Zlaté Hory, Poštovní mine, 29 January 1959, leg. V. Hanák.

Slovakia (5): 2 우 (NMP 91135 [S+B], 91134 [S]), Demänovská Dolina, Dračia cave,

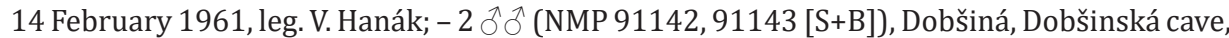
16 February 1968, leg. V. Hanák; - 1 ô (NMP 91145 [S+B]), Tatranská Javorina, Muránska cave, 13 December 1973, leg. J. Gaisler \& V. Hanák. 